\title{
Model Struktural Minat Mahasiswa Berkarir di Bidang Perbankan Syariah Sebagai Dasar Pengembangan Proses Pembelajaran
}

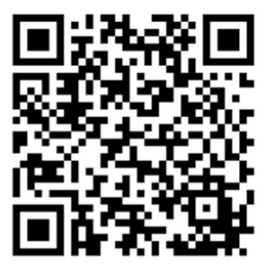

\author{
Mashadi ${ }^{\star}$, Risky Irawan²
}

\begin{abstract}
Abstrak
Perkembangan Perbankan Syariah di Indonesia terus meningkat yang belum diimbangi oleh ketersediaan Sumber Daya Manusia bidang Perbankan Syariah. Sehingga tidak sedikit, Bank Syariah yang melakukan "konversi" SDM Bank Konvensional menjadi SDM Bank Syariah. Pemenuhan kebutuhan SDM Perbankan Syariah sebagian dapat dipenuhi oleh SMK dan Perguruan Tinggi yang menyelenggarakan program studi Perbankan. Namun demikian, tidak semua siswa atau mahasiswa program studi Perbankan bersedia dan berminat menjalani karir sebagai SDM Bank Syariah. Unsur minat menjadi penting untuk membangun optimalisasi kinerja SDM Bank Syariah. Menjadi penting untuk mengetahui secara awal tentang faktor-faktor yang mempengaruhi pembentukan minat para mahasiswa menjalani karir di bidang Perbankan Syariah, mengingat karakteristik karir yang membutuhkan spesifikasi kemampuan khusus dan berbeda dari Bank Konvensional. Tujuan Penelitian ini adalah untuk menganalisis dan mengidentifikasi faktor-faktor yang dominan mempengaruhi para mahasiswa berminat berkarir di bidang Perbankan Syariah. Data diperoleh dari 100 responden Mahasiswa Program Studi Keuangan dan Perbankan STIE Kesatuan diolah menggunakan software SmartPLS 3.0M. Hasil Penelitian menunjukkan bahwa Faktor Persepsi Berkarir dan Faktor Motivasi Berkarir di Bidang Perbankan Syariah para Mahasiswa Keuangan dan Perbankan berpengaruh langsung secara positif dan nyata terhadap terbentuknya Minat Berkarir di Bidang Perbankan Syariah. Faktor Motivasi Berkarir merupakan faktor yang paling tinggi berpengaruh. Persamaan yang dapat dibentuk dari model adalah Minat $=0,076+0,392$ Persepsi $+0,411$ Motivasi. Diperlukan pengembangan model lebih lanjut agar dapat memberi gambaran yang lebih utuh dan komprehensif tentang faktor-faktor yang mempengaruhi terbentuknya minat berkarir di bidang perbankan syariah para mahasiswa.
\end{abstract}

Kata Kunci: minat berkarir, bank syariah, mahasiswa

\section{Pendahuluan}

Indonesia dengan jumlah masyarakat yang tinggi, terus melakukan pengembangan di berbagai sektor pembangunan. Salah satu sektor yang terus mengalami perkembangan adalah sektor industri Perbankan Syariah, baik berkembang pada aspek konsep bisnis dan pelayanannya maupun pada aspek jumlah pelaku bisnis atau entitasnya.

Perkembangan tersebut belum diimbangi oleh ketersediaan Sumber Daya Manusia bidang Perbankan Syariah. Kebutuhan sumberdaya manusia pada industri perbankan syariah mencapai rata-rata 11.000 per tahun. Bahkan menurut salah seorang peneliti Bank Indonesia, gap pemenuhan persediaan SDM perbankan syariah mencapai 20.000 per tahun (Alamsyah, 2012). Sehingga tidak sedikit, Bank Syariah yang melakukan "konversi" SDM Bank Konvensional menjadi SDM Bank Syariah.

Salah satu strategi memenuhi kebutuhan ketersediaan SDM Perbankan Syariah ini adalah melalui pengembangan SDM di Perguruan Tinggi. Namun, jumlah perguruan tinggi yang membuka program studi perbankan pun masih terhitung minim. institusi formal pendidikan di Indonesia hanya mampu
1. Program Studi Manajemen, STIE Kesatuan Bogor, Jl. Ranggagading No. 1 Bogor 16123, Indonesia

2. Cyber Business Indonesia, Yayasan Cendekia Cahaya Cakrawala, Orchard Walk B16 - 17 Bogor Nirwana Residence, Bogor Jawa Barat, Indonesia

EMail mashadi75@yahoo.co.id
JAS-PT

JURNAL ANALISIS SISTEM PENDIDIKAN TINGGI

ISSN 2580 - 5339

Volume 1

Nomor 1

JULI 2017

Hal $1-10$

FORUM DOSEN INDONESIA

.

\section{Submitted : Mei 2017 \\ Accepted \\ Juli 2017}


memasok SDM ekonomi dan keuangan syariah sebanyak 3.750 orang per tahun (swa.co.id, 2013). Hal ini pun masih diperkecil potensi penyediaannya dengan keragaman minat para lulusan perguruan tinggi untuk berkarir di industri Perbankan Syariah.

Tabel 1 Perkembangan Jariangan Kantor Bank Syariah

\begin{tabular}{|c|r|r|r|}
\hline Kelompok Bank & \multicolumn{1}{|c|}{2010} & \multicolumn{1}{|c|}{2011} & \multicolumn{1}{|c|}{2012} \\
\hline Bank Umum Syariah & 11 & 11 & 11 \\
\hline Unit Usaha Syariah & 23 & 24 & 24 \\
\hline$-\quad$ Jumlah Kantor BUS dan UUS & 1477 & 1737 & 2262 \\
\hline BPRS & 150 & 155 & 158 \\
\hline$-\quad$ Jumlah Kantor BPRS & 286 & 364 & 401 \\
\hline
\end{tabular}

Sumber : Bank Indonesia, 2013.

Di tengah kondisi keterbatasan SDM Perbankan Syariah tersebut, menjadi penting untuk semakin memperbesar minat para lulusan Perguruan Tinggi untuk berkarir di Industri Perbankan Syariah. Untuk itu perlu dilakukan penelitian yang mengidentifikasi faktor-faktor yang membentuk minat dimaksud, sehingga dapat menjadi pertimbangan bagi Perguruan Tinggi untuk mengembangkan model atau konsep pembelajaran yang dapat mempertinggi minat para lulusan berkarir di industri Perbankan Syariah.

\section{Identifikasi Masalah}

Ketersediaan SDM Perbankan Syariah belum mampu memenuhi kebutuhan SDM Industri Perbankan Syariah di Indonesia yang tengah berkembang. Minat para lulusan perguruan tinggi untuk berkarir di industri perbankan syariah pun semakin mempertinggi keterbatasan tersebut. Diperlukan strategi sistematis untuk membangun dan meningkatkan minat dimaksud sehingga berimplikasi positif terhadap peningkatan jumlah SDM yang siap berkarir di industri perbankan syariah. Strategi sistematis tersebut dapat terbentuk setelah teridentifikasi faktor-faktor yang membentuk minat tersebut.

\section{Rumusan Masalah}

Rumusan masalah yang diajukan pada penelitian ini adalah sebagai berikut:

1. Adakah pengaruh faktor Persepsi dan faktor Motivasi para Mahasiswa terhadap Minat Berkarir di Industri Perbankan Syariah?

2. Manakah di antara faktor Persepsi dan faktor Motivasi yang mempunyai pengaruh terbesar terhadap Minat Berkarir di Industri Perbankan Syariah?

Tinjauan Pustaka

\section{Bank Syariah}

Pengertian Bank Syariah telah diatur dalam Undang-undang. Pasal 2 PBI No. 6/24/PBI/2004 tentang Bank Umum yang melaksanakan kegiatan usaha berdasarkan Prinsip Syariah, memberikan definisi bahwa Bank umum syariah adalah bank yang melaksanakan kegiatan usaha berdasarkan prinsip syariah yang dalam kegiatannya memberikan jasa dalam lalu lintas pembayaran. Bentuk hukum yang diperkenankan adalah perseroan terbatas atau PT.

Secara garis besar hubungan ekonomi berdasarkan syariah Islam tersebut ditentukan oleh hubungan akad yang terdiri dari lima konsep dasar akad. Bersumber dari lima dasar konsep inilah dapat ditemukan produk-produk lembaga keuangan bank syariah dan lembaga keuangan bukan bank syariah untuk dioperasionalkan. Kelima konsep tersebut adalah : (1) sistem simpanan, (2) bagi hasil, (3) margin keuntungan, (4) sewa, (5) jasa (fee). Kegiatan utama perbankan syariah tersebut harus menggunakan prinsip dasar bank syariah yang ditetapkan, yaitu: Mudharabah, Musyarakah, Wadi'ah, Murabahah, Salam, Istishna', Ijarah, Qardh, Rahn, Hiwalah/Hawalah, dan Wakalah.

\section{Persepsi}

Persepsi merupakan salah satu aspek psikologis yang penting bagi manusia dalam merespon kehadiran berbagai aspek dan gejala di sekitarnya. Persepsi mengandung pengertian yang sangat luas, menyangkut intern dan ekstern. Menurut Kamus Besar Bahasa Indonesia, persepsi adalah tanggapan 
(penerimaan) langsung dari sesuatu. Proses seseorang mengetahui beberapa hal melalui panca inderanya.

Persepsi adalah kemampuan otak dalam menerjemahkan stimulus atau proses untuk menerjemahkan stimulus yang masuk ke dalam alat indera manusia. Persepsi manusia terdapat perbedaan sudut pandang dalam penginderaan. Ada yang mempersepsikan sesuatu itu baik atau persepsi yang positif maupun persepsi negatif yang akan mempengaruhi tindakan manusia yang tampak atau nyata (Sugihartono, dkk, 2007). Suharman (2005: 23) menyatakan: "persepsi merupakan suatu proses menginterpretasikan atau menafsir informasi yang diperoleh melalui sistem alat indera manusia". Menurutnya ada tiga aspek di dalam persepsi yang dianggap relevan dengan kognisi manusia, yaitu pencatatan indera, pengenalan pola, dan perhatian. Dengan demikian, persepsi dapat dimaknai sebagai suatu proses yang dimulai dari penglihatan hingga terbentuk tanggapan yang terjadi dalam diri individu sehingga individu sadar akan segala sesuatu dalam lingkungannya melalui indera-indera yang dimilikinya.

\section{Motivasi}

Motivasi dapat dimaknai sebagai keinginan (desire) dari dalam yang mendorong seseorang untuk bertindak. Kata motif disamakan artinya dengan kata motive, dorongan, dan alasan. Motif adalah daya pendorong atau tenaga pendorong yang mendorong manusia untuk bertindak atau suatu tenaga di dalam diri manusia yang menyebabkan manusia tersebut bertindak. Dengan kata lain dapat dinyatakan bahwa tingkah laku seseorang dalam beraktivias atau bekerja dapat muncul atau timbul karena adanya motive (motive are the way of behaviour).

Motivasi pada dasarnya adalah kondisi mental yang mendorong dilakukannya suatu tindakan (action/activities) dan memberikan kekuatan (energy) yang mengarah kepada pencapaian kebutuhan, memberi kepuasan, atau mengurangi ketidakseimbangan. Motivasi merupakan proses untuk mencoba mempengaruhi seseorang agar melakukan sesuatu yang kita inginkan. Menurut Barelson dan Steiner dikatakan bahwa istilah motif sebagai suatu keadaan di dalam diri seseorang (inner state) yang mendorong, mengaktifkan, atau mengerahkan (karenanya "motivasi"), dan mengarahkan atau menyalurkan perilaku ke arah tujuan. Motivasi berarti suatu kondisi yang mendorong atau menjadi penyebab seseorang melakukan sesuatu perbuatan atau kegiatan yang berlangsung secara sadar, Hadari Nawasi, (1997:351).

\section{Minat Berkarir}

Minat adalah sumber motivasi yang mendorong seseorang untuk melakukan apa yang ingin dilakukan bila seseorang bebas memilih. Ketika seseorang menilai bahwa sesuatu akan bermanfaat, maka akan terbentuk minat yang kemudian hal tersebut akan mendatangkan kepuasan. Ketika kepuasan menurun maka minatnya juga akan menurun sehingga minat tidak bersifat permanen, tetapi bersifat sementara atau dapat berubah-ubah (Hurlock dalam Riyanti 2003).

Minat berkarir di Industri Perbankan Syariah adalah tanggapan individu terhadap ketertarikannya akan profesi bankir bahwa profesi ini dianggap sebagai pekerjaan yang menjanjikan secara finansial dan non finansial.

Kerangka Berpikir

Kerangka berpikir penelitian ini secara sederhana digambarkan sebagai berikut :

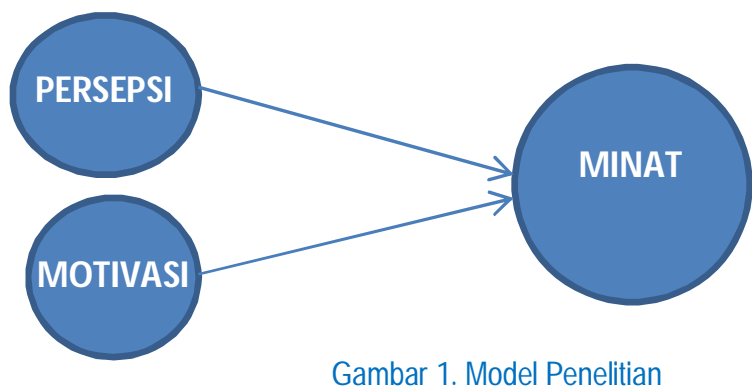


Hipotesis

Berdasarkan kerangka berpikir di atas maka dibuat hipotesis sebagai berikut:

$\mathrm{H}_{1} \quad$ : Persepsi berpengaruh positif dan signifikan terhadap Minat Berkarir

$\mathrm{H}_{2} \quad$ : Motivasi berpengaruh positif dan signifikan terhadap Minat Berkarir

Metodologi Penelitian

\section{Tempat dan Waktu Penelitian}

Penelitian ini dilakukan di Sekolah Tinggi Ilmu Ekonomi Kesatuan Bogor dengan menjadikan mahasiswa program studi Keuangan dan Perbankan sebagai responden dan dilaksanakan pada bulan Januari Februari 2017.

\section{Jenis Penelitian}

Penelitian ini merupakan penelitian asosiatif dan penelitian kuantitatif, yang menganalisis data kuantitatif (data yang berbentuk angka atau data kualitatif yangdikuantitatifkan) dengan menggunakan statistika sebagai alat uji.

\section{Populasi dan Teknik Pengambilan Sampel}

Populasi penelitian ini adalah para mahasiswa STIE Kesatuan Bogor Program Studi Keuangan dan Perbankan. Sampel ditetapkan dengan metode pengambilan sampel quota sampling yang dilakukan dengan mengambil sampel berdasarkan kriteria tertentu (Jogiyanto, 2008), dimana pertimbangan responden yang diminta mengisi kuesioner, yaitu para mahasiswa yang telah mengikuti pembelajaran perbankan sejumlah 100 orang responden.

\section{Alat Pengumpulan Data}

Alat dan Metode pengumpulan data dalam penelitian ini adalah:

- Wawancara (interview) lisan yang dilakukan kepada Ketua Program Studi Keuanan dan Perbankan STIE Kesatuan Bogor.

- Daftar pertanyaan (questionaire) yang diberikan kepada responden penelitian.

- Studi dokumentasi dengan mempelajari data-data yang berasal dari STIE Kesatuan.

\section{Teknik Analisa Data}

Untuk menganalisis data digunakan pendekatan Partial Least Square (PLS). PLS adalah model persamaan Structural Equation Model (SEM) yaitu suatu teknik modeling statistika yang merupakan kombinasi dari analisis principal component, analisis regresi dan analisis jalur (Joko, 2010). SEM merupakan metode analisis data multivariatyang bertujuan menguji model pengukuran dan model struktural variabel laten (Kusnendi, 2008). Secara teknis SEM dikembangkan berdasarkan dua kelompok yaitu SEM berbasis kovarian yang diwakili LISREL dan SEM berbasis varian yang paling dominan adalah Partial Least Square (PLS). Menurut Ghozali (2006), PLS merupakan pendekatan alternatif yang bergeser dari pendekatan SEM berbasis kovarian menjadi berbasis varian. SEM yang berbasis kovarian umumnya menguji kausalitas/teori sedangkan PLS lebih bersifat predictive model.

Tujuan PLS adalah membantu peneliti untuk mendapatkan nilai variabel laten untuk tujuan prediksi. Model formalnya mendefinisikan variabel laten adalah linier agregat dari indikator-indikatornya (Ghozali, 2008). PLS merupakan metode analisis yang powerfull (Ghozali, 2006), karena tidak didasarkan pada banyak asumsi. Misalnya, data harus terdistribusi normal, sampel tidak harus besar. Selain dapat digunakan untuk mengkonfirmasi teori, PLS juga dapat digunakan untuk menjelaskan ada tidaknya hubungan antar variabel laten. PLS dapat sekaligus menganalisis konstruk yang dibentuk dengan indikator reflektif dan formatif. Model formalnya mendefinisikan variabel laten adalah linear agregat dari indikator-indikatornya. Weight estimate untuk menciptakan komponen skor variable laten didapat berdasarkan bagaimana inner model (model struktural yang menghubungkan antar variabel laten) dan outer model (model pengukuran yaitu hubungan antara indikator dengan konstruknya) dispesifikasi. Hasilnya adalah residual variance dari variabel dependen. Estimasi parameter yang didapat dengan PLS dapat dikategorikan menjaditiga. Pertama, adalah weight estimate yang digunakan untuk menciptakan skorvariabel laten. Kedua, mencerminkan estimasi jalur (path estimate) yangmenghubungkan variabel laten dan antar variabel laten dan indikatornya(loading). Ketiga, berkaitan dengan means dan lokasi parameter (nilai konstanta regresi) untuk indikator dan variabel laten. Untuk memperoleh ketiga estimasi ini,PLS menggunakan proses iterasi 3 tahap dan setiap tahap iterasi menghasilkan estimasi. Tahap 
pertama, menghasilkan weight estimate, tahap kedua menghasilkan estimasi untuk inner model dan outer model, dan tahap ketiga menghasilkan estimasi means dan lokasi (Ghozali, 2006).

Software untuk menganalisis SEM component based PLS pertama kali dikembangkan oleh Jan-Bernd Lohmoller under DOS dan disebut LVPLS versi 1.8 (Latent Variable Partial Least Squares) (Ghozali, 2008). Kemudian software tersebut dikembangkan oleh beberapa ahli setelahnya. Di University of Hamburg Jerman dikembangkan pula software PLS yang diberi nama SMARTPLS versi $2.0 \mathrm{M}$ yang kemudian berkembang menjadi SMARTPLS Versi 3.0 M yang digunakan dalam mengolah data pada penelitian ini.

\section{Hasil Dan Pembahasan}

\section{Karakteristik Responden}

Jumlah responden yang menjadi sampel dalam penelitian ini berjumlah 100 orang mahasiswa Program Studi Keuangan dan Perbankan di STIE Kesatuan.

Tabel 2. Sebaran Sampel Berdasarkan Karakteristik Responden

\begin{tabular}{|c|c|c|c|}
\hline \multicolumn{2}{|c|}{ Karakteristik Responden } & Frekuensi & $\%$ \\
\hline \multirow[t]{3}{*}{ Jenis Kelamin } & Laki-laki & 16 & 16.0 \\
\hline & Wanita & 84 & 84.0 \\
\hline & Total & 100 & 100 \\
\hline \multirow[t]{4}{*}{ Semester } & II (Dua) & 0 & 0 \\
\hline & IV (Empat) & 47 & 47.0 \\
\hline & VI (Enam) & 53 & 53.0 \\
\hline & Total & 100 & 100 \\
\hline \multirow[t]{6}{*}{ Pilihan Karir } & Pegawai Bank Indonesia & 56 & 56.0 \\
\hline & Konsultan Perbankan Syariah & 6 & 6.0 \\
\hline & $\begin{array}{l}\text { Ahli Perbankan Syariah di } \\
\text { Perusahaan }\end{array}$ & 20 & 20.0 \\
\hline & Pemilik Bank Syariah & 10 & 10.0 \\
\hline & Lainnya & 8 & 8.0 \\
\hline & Total & 100 & 100 \\
\hline
\end{tabular}

Sumber: Data Primer Diolah, 2017

\section{Analisis Model Minat Berkarir}

Studi empiris dilakukan terlebih dahulu untuk membentuk model awal minat berkarir di Bank Syariah. Dalam penelitian ini, variabel Minat Berkarir dipengaruhi oleh dua variabel yaitu Persepsi dan Motivasi, dengan lima indikator untuk masing-masing variabel. Pemilihan dan penetapan rujukan dalam membangun model menjadi perhatian mendalam dalam proses penelitian ini, dengan tujuan agar model yang dibangun adalah model yang terbaik serta teruji secara nomologis.

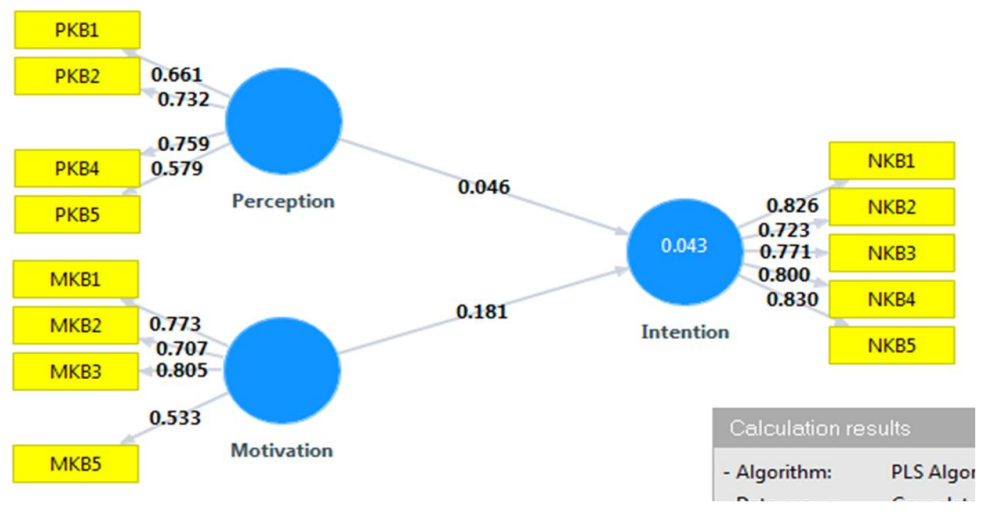

Gambar 2. Model Final Minat Berkarir di Bank Syariah

Model Awal Penelitian ini dianalisis menggunakan software SmartPLS untuk memperoleh model terbaik. Tampilan hasil PLS Algorithm pada Model Minat Berwirausaha sebagaimana disajikan dalam Gambar 2. Dalam Model tersebut dapat diketahui indikator dari masing-masing variabel memiliki nilai loadingfactor 
positif dan di atas 0,500 . Terdapat sebagian kecil indikator yang memiliki nilai loading factor di bawah 0,500 . Untuk itu perlu dilakukan penyesuaian model, dengan mengeluarkan indikator yang bernilai di bawah 0,500 (Chin, 1998) agar fit of model terpenuhi untuk dijadikan sebagai Model Final Minat Berkarir di Bank Syariah serta dilakukan analisis selanjutnya.

Dalam Model Final tersebut, ada indikator yang dikeluarkan, yaitu PKB3 dan MKB4, yang memiliki nilai loading factor di bawah 0.500. Responden penelitian ini belum sepakat untuk menyatakan secara bersama-sama tentang perlunya mengikuti pelatihan untuk pengembangan karir di bank syariah sebelum proses berkarir tersebut dijalankan (PKB3). Demikian pula responden tidak sepakat untuk menyatakan bahwa memperoleh penghasilan tambahan yang tinggi sebagai motivasinya untuk menjalani karir di Bank Syariah (MKB4).

\section{Evaluasi Pengukuran Model (Model Measurement Evaluation)}

Proses PLS Algorithm lanjutan atas model final Minat Berkarir di Bank Syariah menghasilkan nilai crossloading untuk setiap variabel indikator. Dalam Gambar 2 terlihat bahwa semua indikator memiliki nilai loading factor di atas 0,50 . Sebagai ilustrasi, indikator-indikator variabel Minat Berkarir memiliki nilai loading factor antara 0,579 sampai dengan 0,759: indikator MKB1 sebesar 0,661; indikator MKB2 sebesar 0,732; indikator MKB3 sebesar 0,759 dan indikator MKB5 sebesar 0,579. Demikian pula dengan indikator lainnya memiliki nilai loading factor di atas 0,50 . Hal ini dapat disimpulkan bahwa konstruk mempunyai convergentvalidity yang baik.

Nilai crossloading menunjukkan pula adanya discriminate validity yang baik oleh karena nilai korelasi indikator terhadap konstruknya lebih tinggi dibandingkan nilai korelasi indikator dengan konstruk lainnya. Sebagai ilustrasi, nilai crossloading indikator MKB1 terhadap variabel/konstruk Motivasi adalah sebesar 0,773 yang lebih tinggi dari nilai crossloading dengan konstruk lain, yaitu dengan Persepsi $(0,293)$ dan dengan Minat Berkarir $(0,177)$. (Lihat Tabel 3). Hal serupa tampak pula pada indikator-indikator Persepsi dan Minat Berkarir.

Tabel 3. Nilai CrossLoading indikator-indikator dalam Model Minat Berkarir di Bank Syariah Mahasiswa STIE Kesatuan Bogor

\begin{tabular}{|l|r|r|r|}
\hline & Intention & Motivation & Perception \\
\hline MKB1 & 0.177 & 0.773 & 0.293 \\
\hline MKB2 & 0.127 & 0.707 & 0.455 \\
\hline MKB3 & 0.175 & 0.805 & 0.441 \\
\hline MKB5 & 0.059 & 0.533 & 0.307 \\
\hline NKB1 & 0.826 & 0.144 & 0.096 \\
\hline NKB2 & 0.723 & 0.084 & 0.180 \\
\hline NKB3 & 0.771 & 0.106 & 0.004 \\
\hline NKB4 & 0.800 & 0.147 & 0.064 \\
\hline NKB5 & 0.830 & 0.243 & 0.156 \\
\hline PKB1 & 0.082 & 0.412 & 0.661 \\
\hline PKB2 & 0.085 & 0.394 & 0.732 \\
\hline PKB4 & 0.133 & 0.288 & 0.759 \\
\hline PKB5 & 0.053 & 0.410 & 0.579 \\
\hline
\end{tabular}

Sumber : Data Primer Diolah, 2017

Di samping uji validitas konstruk, dilakukan pula uji reliabilitas konstruk yang diukur dengan composite reliability dari blok indikator yang mengukur konstruk.

Tabel 4 Nilai Composite Reliability Variabel Laten dalam Model Minat Berkarir di Bank Syariah Mahasiswa STIE Kesatuan Bogor

\begin{tabular}{lcc} 
& Variabel & Nilai Composite Reliability \\
\hline Minat Berkarir & 0.893 \\
Motivasi & 0.801 \\
Persepsi & 0.779 \\
\hline
\end{tabular}

Sumber : Data Primer Diolah, 2017 
Reliabilitas suatu Konstruk ditandai dengan nilai composite reliability di atas 0,70. Tabel 4 menunjukkan semua konstruk memiliki nilai composite reliability di atas 0,70 . Sehingga dapat disimpulkan bahwa konstruk memiliki kehandalan yang baik. Selain menggunakan nilai composite reliability, untuk menilai reliabilitas suatu konstruk dapat juga dilakukan dengan melihat AverageVarianceExtracted (AVE) yang membandingkan nilai akar AVE dengan nilai korelasi antar konstruk.

Tabel 5. Nilai AVE dan Akar AVE Variabel-variabel dalam Model Minat Berkarir di Bank Syariah Mahasiswa STIE Kesatuan Bogor

\begin{tabular}{|c|c|c|}
\hline Variabel & AVE & Akar AVE \\
\hline Minat Berkarir & 0.626 & 0.791 \\
\hline Motivasi & 0.507 & 0.712 \\
\hline Persepsi & 0.471 & 0.686 \\
\hline
\end{tabular}

Sumber : Data Primer Diolah, 2017

Nilai akar AVE masing-masing variabel (lihat Tabel 5) menunjukkan nilai yang lebih tinggi dibandingkan dengan nilai korelasi antar konstruk dengan konstruk lainnya (lihat Tabel 6) dan hal ini mengandung makna bahwa konstruk memiliki discriminant validity yang tinggi. Nilai AVE konstruk Minat Berkarir pada tabel 5 adalah 0.626 sehingga nilai akarnya adalah sebesar 0.791 . Nilai akar AVE tersebut lebih tinggi daripada nilai korelasi antara konstruk Minat Berkarir dengan konstruk yang lainnya yaitu sebesar 0,255 (Minat Berkarir dengan Motivasi) dan 0,139 (Minat Berkarir dengan Persepsi). Dengan kondisi demikian dapat dinyatakan bahwa model adalah baik.

Tabel 6. Korelasi Antar Konstruk Laten Dalam Model Minat Berkarir di Bank Syariah Mahasiswa STIE Kesatuan Bogor

\begin{tabular}{lrcc}
\hline \multicolumn{1}{c}{ VARIABEL } & Minat & Motivasi & Persepsi \\
\hline Minat & 1.000 & & \\
Motivasi & 0.255 & 1.000 & \\
Persepsi & 0.139 & 0.514 & 1.000 \\
\hline
\end{tabular}

Sumber : Data Primer Diolah, 2017

\section{Evaluasi Struktural Model (Model Structural Evaluation)}

Evaluasi Struktural Model (Inner) dilakukan untuk menggambarkan model konstruk antar variabel laten. Variabel laten endogenous dalam model yaitu Minat Berkarir dipengaruhi secara langsung oleh konstruk Persepsi dan konstruk Motivasi.

Tabel 7. Nilai R - Square Konstruk Endogen dalam Model Minat Berkarir di Bank Syariah Mahasiswa STIE Kesatuan Bogor

\begin{tabular}{ll}
\hline \multicolumn{1}{c}{ VARIABEL } & Minat \\
\hline Minat Berkarir & 0.043 \\
\hline Sumber: Data Primer Diolah, 2017 &
\end{tabular}

Konstruk Minat Berkarir dipengaruhi oleh konstruk Persepsi dan Motivasi memiliki nilai R2 sebesar 0,043 (lihat Tabel 7). Hal tersebut mengandung makna bahwa kedua variabel tersebut mampu menjelaskan variability konstruk Minat Berkarir sebesar 4,3\% dan sisanya sebesar 93,7\% dijelaskan oleh variabel lain yang tidak disertakan dalam model. Chin (1998) mengelompokkan nilai $\mathrm{R}^{2}$ ke dalam tiga kategori pemaknaan yaitu substansial $(0.67)$, Moderat $(0,33)$ dan Lemah $(0,19)$. Dengan demikian dapat dinyatakan bahwa variabel Minat Berkarir memiliki $\mathrm{R}^{2}$ atau kontribusi variabel eksogennya yang berada pada level lemah. Selanjutnya, dilakukan pengujian hipotesis menggunakan nilai yang terdapat dalam output result for inner weight.

Tabel 8 Nilai Hasil Uji Bootstrap Koefisien Jalur Konstruk Minat Berkarir

\begin{tabular}{|c|c|c|c|c|}
\hline KONSTRUK & $\begin{array}{c}\text { Original } \\
\text { Sample (0) }\end{array}$ & $\begin{array}{c}\text { T Statistics } \\
\text { (|O/STERR|) }\end{array}$ & Kesimpulan & Keputusan \\
\hline $\begin{array}{l}\text { MOTIVASI -> } \\
\text { MINAT BERKARIR }\end{array}$ & 0.190718 & 1.964055 & $\begin{array}{l}\text { Berpengaruh Positif, } \\
\text { Signifikan }\end{array}$ & H1 Diterima \\
\hline $\begin{array}{l}\text { PERSEPSI -> } \\
\text { MINAT BERKARIR }\end{array}$ & 0.277344 & 2.637519 & $\begin{array}{l}\text { Berpengaruh Positif, } \\
\text { Signifikan }\end{array}$ & H2 Diterima \\
\hline
\end{tabular}

Sumber : Data Primer Diolah, 2017 


\section{Pembahasan}

Dengan memperhatikan hasil uji hipotesis pada Tabel 8, Faktor Motivasi dan Faktor Persepsi yang berpengaruh secara nyata terhadap pembentukan minat berkarir Mahasiswa STIE Kesatuan di Bidang Perbankan Syariah. Hal ini dapat dilihat dari nilai original sampel $(0)$ Motivasi $(0,191)$ dan Persepsi $(0,277)$ yang bernilai positif serta nilai $t$-statistics $(|\mathrm{O} / \mathrm{STERR}|)$ Motivasi $(1,964)$ dan Persepsi $(2,638)$ yang melebihi nilai 1,96 .

Dari nilai original sampel pun dapat ditentukan bahwa faktor Persepsi memiliki pengaruh paling tinggi terhadap minat berkarir di bidang Perbankan Syariah Mahasiswa STIE Kesatuan Bogor $(0,277>0,191)$. Faktor Persepsi memiliki nilai original sampel 0,086 lebih tinggi dibanding faktor Motivasi. Hal ini menunjukkan bahwa para Mahasiswa STIE Kesatuan secara umum masih dipengaruhi oleh persepsi yang terbentuk dalam benaknya untuk berkarir di bidang perbankan syariah. Persepsi tersebut akan banyak dibentuk oleh lingkungan sekitar mahasiswa tersebut mulai dari keluarga sampai dengan para sahabatnya.

Minat berkarir di bidang perbankan syariah akan semakin meningkat saat persepsi tentang perbankan syariah dalam benak para mahasiswa dibangun dengan citra yang baik. Empat persepsi yang telah terbangun di benak para mahasiswa adalah bahwa untuk berkarir di bidang perbankan syariah dibutuhkan proses perkuliahan dan peningkatan pengetahuan terkait perbankan syariah, berkarir di bidang perbankan syariah diperlukan kemampuan analitis, decision making dan problem solving serta kemampuan interpersonal untuk dapat saling bekerjasama dalam kelompok. Keempat indikator tersebut dipersepsikan kuat oleh para responden yang akan meningkatkan minat berkarir di bidang perbankan syariah.

Minat Mahasiswa untuk Berkarir di Perbankan Syariah akan meningkat pula saat faktor internal mahasiswa yang melatarbelakanginya berada pada kondisi baik. Salah satu faktor internal tersebut adalah Motivasi Berkarir di Perbankan Syariah. Motivasi dimaksud antara lain ingin mendapatkan pekerjaan yang sesuai dengan latar belakang pendidikan. Para responden yang merupakan mahasiswa Program Studi Keuangan dan Perbankan, sangat termotivasi untuk memperoleh pekerjaan di bidang Perbankan Syariah dengan pertimbangan adanya kesesuaian dengan latar belakang keilmuan dan pendidikan yang dimilikinya. Selain itu, para mahasiswa termotivasi pula untuk meningkatkan keahliannya dalam mengaplikasikan pengetahuan perbankan untuk memecahkan permasalahan riil dalam kehidupan sehari-hari khususnya terkait perbankan syariah. Para mahasiswa sangat ingin meningkatkan kemampuan berprestasinya dalam pekerjaan yang sesuai dengan minat dan kompetensi mereka. Motivasi lain para mahasiswa adalah ingin memperoleh pengetahuan berkaitan dengan peran dan tanggungjawab yang akan dimiliki ketika berada di tengah-tengah masyarakat.

Implikasi manajerial bagi dunia pendidikan perlu dibangun pola dan proses pembelajaran yang mengarahkan persepsi dan motivasi mahasiswa tentang perbankan syariah dan berkarir di dalamnya. Dukungan serta pengkondisian lingkungan agar mahasiswa termotivasi berkarir di perbankan syariah pun menjadi penting dilakukan. Beberapa materi utama yang harus menjadi bagian dalam proses pembelajaran bagi mahasiswa yang berminat berkarir di Perbankan Syariah adalah pengetahuan terkait perbankan syariah, pembelajaran yang meningkatkan kemampuan analitis, decision making dan problem solving serta kemampuan interpersonal untuk dapat saling bekerjasama dalam kelompok.

Penutup

1. Kesimpulan

Kesimpulan yang dapat diambil dari pembahasan penelitian ini adalah antara lain :

1. Faktor Motivasi berpengaruh secara nyata terhadap Minat Mahasiswa Berkarir di Perbankan Syariah

2. Faktor Persepsi berpengaruh secara nyata terhadap Minat Mahasiswa Berkarir di Perbankan Syariah

3. Diperlukan pengembangan pembelajaran pada diri Mahasiswa dengan memperkuat aspek Motivasi dan Persepsi tentang Perbanka Syariah.

4. Faktor Motivasi dan Persepsi secara bersama-sama hanya mampu menjelaskan variability konstruk minat berkarir di Perbankan Syariah pada level sangat lemah yaitu 4,3\%. Sisanya sebesar 93,7\% dipengaruh oleh variabel lain yang tidak dijelaskan oleh model.

\section{Saran}

Saran yang dapat dikemukakan pasca penelitian ini adalah sebagai berikut:

1. Para akademisi dengan dukungan kebijakan pemerintah hendaknya mampu menciptakan dan mengembangkan program pembelajaran perbankan syariah bagi Mahasiswa secara terintegrasi antara pemahaman teori dan pengalaman praktis. 
2. Perlu dikembangkan lebih lanjut model minat berkarir di perbankan syariah dengan memasukkan indikator-indikator atau teori lain untuk melengkapi kekurangan model yang digunakan dalam penelitian ini.

3. Perlu dikembangkan penelitian ini terhadap obyek penelitian lainnya, seperti Siswsa SMK.

Daftar Pustaka

Alamsyah, Halim, 2012. Perkembangan Dan Prospek Perbankan Syariah Indonesia: Tantangan Dalam Menyongsong MEA 2015,yang disampikan dalam Milad ke-8 Ikatan Ahli Ekonomi Islam (IAEI) tanggal 13 April 2012.

Bank Indonesia, 2004. Peraturan Bank Indonesia. No. 6/24/PBI/2004 tentang Bank Umum yang melaksanakan kegiatan usaha berdasarkan Prinsip Syariah, Pasal 2. Bank Indonesia, Jakarta.

Bank Indonesia, 2013. Laporan Perkembangan Perbankan Syariah 2012. Departemen Perbankan Syariah Bank Indonesia, Jakarta.

Ghozali, I. 2007. Aplikasi Analisis Multivariate dengan Program SPSS. Cetakan Keempat. Badan Penerbit Universitas Diponegoro, Semarang

Ghozali, I. 2006. Structural Equation Modeling Metode Alternatif dengan Partial Least Square (PLS) Semarang: Badan Penerbit UNDIP

Ghozali, I. 2008. Model Persamaan Struktural Konsep dan Aplikasi dengan Program Amos 16.0. Semarang: Badan Penerbit UNDIP.

Hadari Nawawi, 1997. Manajemen Sumber Daya Manusia untuk Bisnis yang Kompetitif, Gadjah Mada University Press, Yogyakarta.

Mulyana, M., 2012. Consumer Behaviour: Sukses Dengan Memahami Konsumen. ISBN 978-979-185316-3, Bogor: Kesatuan Press.

Mulyana, M. and Maulana, M., 2013. Pengaruh Pelayanan Terhadap Kepuasan Pelanggan dan Implikasinya Terhadap Citra Perusahaan. Jurnal IImiah Manajemen Kesatuan, 1(2).

Nawawi, Hadari. 1997. Manajemen Sumber Daya Manusia Untuk Bisnisyang Kompetitif. Gajah Mada University-Press, Yogyakarta.

Nurendah, Y. and Mulyana, M., 2013. Analisis Pengaruh Kualitas Pelayanan Perpustakaan Terhadap Kepuasan dan Hubungannya dengan Loyalitas Mahasiswa. Jurnal IImiah Manajemen Kesatuan, 1(1), pp.91-105.

Riyanti, Benedicta Prihatin Dwi, 2003. Kewirausahaan Dipandang dari Sudut Pandang Psikologi Kepribadian, Cetakan Pertama, Penerbit PT Grasindo,Jakarta.

Sugihartono, dkk. 2007. Psikologi Pendidikan. Yogyakarta: UNY Press.

Suharman. 2005. Psikologi Kognitif. Jakarta; Aneka Karyacipta

Sulistiono, S. and Mubarak, M.M., 2012. Strategi Pengembangan Pemasaran UKM Pengrajin Sepatu Sandal. Jurnal IImiah Ranggagading (JIR), 12(1), pp.halaman-63.

Wahyono, Budi, 2013. Analisis prospek Kontribusi ekonomi syariah di Indonesia, http://ekonomisyariah.info/blog/2013/09/26/analisis-prospek-kontribusi-ekonomisyariah-di-indonesia/ 
10| JURNAL ANALISIS SISTEM PENDIDIKAN TINGGI | VOL. 1 NO. 1 2017, pp. 1-10 